\section{I forkant av moderne helsebyråkrati}

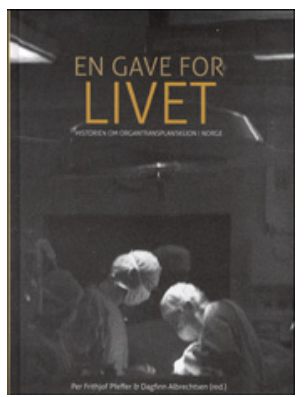

Per Frithjof Pfeffer, Dagfinn Albrechtsen, red. En gave for livet

Historien om organtransplantasjon i Norge. 295 s, tab, ill. Oslo: Unipub, 2011. Pris NOK 300 ISBN 978-82-303-1830-0

Hensikten med denne utgivelsen er å fremlegge en moderne medisinsk historie hvor relativt få personer i et lokalt fagmiljø i Oslo initierte og organiserte et nasjonalt behandlingstilbud. Forfatterne har prøvd å gjøre stoffet mest mulig forståelig for dem som ikke arbeider innen helse, noe som alltid vil være vanskelig. Boken bør være obligatorisk lesning for helsebyråkrater, av stor verdi for helsepersonell og som «illustrert vitenskap» for et bredere publikum. Organiseringen og gjennomføringen av organtransplantasjon i Norge er i dag en internasjonal spissfunksjon.

Det er 15 kapitler, blant annet: Fra drøm til virkelighet, Kroppen avstøter fremmed vev, Organdonasjon fra avdøde og levende givere, Transplantasjonssykepleie, Bindeleddet til pasientforeninger og interesseorganisasjoner og Et blikk inn i fremtiden. I tillegg er det sju kapitler om transplantasjon av ulike organer. Kapitlene har ulike forfattere og forfattergrupper.

Bidragsyterne nevner fortjenstfullt mange navn. Det er riktig at de fleste av disse nevnes og at vi făr historien om livet de levde, hvordan de arbeidet, hvordan de tenkte og hvordan de organiserte et konglomerat av krav til basalforskning, tverrfaglig samarbeid på Rikshospitalet og nasjonalt, og ikke aller minst kravet til religion og etikk. Dette var en tid da idérikdom, evne til samarbeid og improvisasjon var de største intellektuelle utfordringene.

Verdens første vellykkede nyretransplantasjon ble utført i 1953 og i Norge to år senere (1). Den første tiden var dette eksperimentell medisin. Den første langvarige vellykkede nyretransplantasjonen fant sted i 1963. På denne tiden ble HLA-vevstyping etablert, og i slutten av 1960-årene ble moderne nyretransplantasjon etablert i Norge. Forskning, organisering og personer fra dette miljøet var grunnleggende og kontaktskapere for transplantasjon av andre organer og av flere organer samtidig. Resultatene ble dokumentert lenge før systematisk kvalitetssikring ble et moteord. Med denne korte historien er det nå utført nærmere 10000 transplantasjoner i Norge.

Historien er av stor interesse. I forordet summerer forfatterne opp historien og kjernepunktene på en oversiktig måte. Det er mange detaljopplysninger, men av historiske hensyn bør de være der. Både disse opplysningene og enkeltpersoner kan det være vanskelig for uinnvidde å forholde seg til, men man kan imidlertid lese boken som en historisk roman med autentiske personer. Det er en rekke fine illustrasjoner, og spesielt $i$ de to første kapitlene er det nyttige faktabokser for leseren. På de siste seks sidene presenteres forfatterne.

Tre personer i denne historien bør nevnes: Ole Jacob Malm (1910-2005) som, før vevstyping var tilgjengelig, testet avstøtningsreaksjon ved å transplantere hudlapper på sin egen underarm, Erik Thorsby (f. 1938) som etablerte og utviklet HLA-vevstyping, og Audun Flatmark (1926-2004), kirurgen og organisatoren av det nasjonale nyretransplantasjonsprosjektet. Alle var hovedaktører som la grunnlaget for det nasjonale transplantasjonsprogrammet vi har i dag.

\section{Tor-Erik Widerøe}

Det medisinske fakultet

Norges teknisk-naturvitenskapelige universitet

\section{Litteratur}

1. Thorsby E. Norsk transplantasjonsmedisin gjennom 50 år. Tidsskr Nor Laegeforen 2006: 126: 3305-10.

\section{Hvordan utdanne en kirurg}

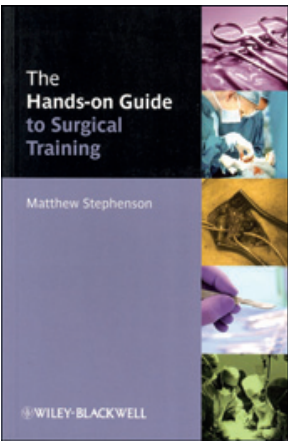

Matthew Stephenson

The hands-on guide to surgical training

304 s, tab, ill. Chichester: Wiley-Blackwell, 2012. Pris GBP 20

ISBN 978-0-470-67261-7

Spesialistutdanningen innen de medisinske fagområdene er i søkelyset av flere grunner: Faglig innhold og struktur, nye arbeidstidsbestemmelser, endrede sosiale trender og ulike aspekter knyttet til rekruttering er noen av disse. Kirurgifaget er intet unntak. Denne boken er ment som en praktisk veileder - både til å komme inn i en kirurgisk spesialistutdanning og deretter til grenspesialisering. Men boken er også en veiledning i å kunne komme gjennom årene i kirurgisk utdanningsstilling, og underveis gjøre personlige og gode veivalg for sin egen fremtidige yrkeskarriere, både faglig og sosialt.

Alle bidragsyterne arbeider i det britiske helsevesenet. Deres utgangspunkt er rekruttering til og gjennomføring av spesialistutdanningen innen dette systemet. Selv om deler av innholdet derfor blir noe mindre relevant for norske spesialistkandidater, inneholder boken en rekke betraktninger og en god del informasjon og gode råd av mer generell karakter. For eksempel er det relativt uvanlig å finne i skriftlig form såpass detaljerte beskrivelser av hvilke forventninger man har til spesialistkandidatenes bidrag og atferd på sengepost, operasjonsavdeling og poliklinikk. Og det generelle budskapet hva gjelder vår omgang med pasienter, kolleger og medarbeidere for øvrig er: «It's nice to be important, but it's more important to be nice.» Ikke dårlig hvis man kan få med seg en slik betraktning når man starter på en spesialistutdanning - om denne innsikten skulle ha glippet helt under studietiden.

Man finner også korte beskrivelser av hva som preger de ulike hoved- og grenspesialitetene innen kirurgifaget. Et kort kapittel er spesielt viet rekruttering av kvinner, uten at jeg tror mange kvinner vil bli spesielt motivert av disse tre sidene.

Boken har frakkelommeformat, er lett å slå opp i og har indeks bakerst, men skriften er liten. Bildene er gjennomgående små og egner seg lite til å illustrere teksten.

Både sentrale og lokale aktører som engasjerer seg i spesialistutdanningen vil kunne finne en del faktaopplysninger og vurderinger som kan bidra til å gjøre nødvendige endringer i vår egen spesialistutdanning - både til utdanningen, men kanskje også til dannelsen av fremtidens kirurger.

\section{Jon Arne Søreide}

Gastrokirurgisk avdeling

Stavanger universitetssjukehus 